\title{
Dedicated Herbaceous Biomass Feedstock Genetics and Development
}

\author{
W. F. Anderson ${ }^{1}$ - G. Sarath ${ }^{2}$ - S. Edme ${ }^{2}$ - M. D. Casler ${ }^{3}$ - R. B. Mitchell ${ }^{2}$. \\ C. M. Tobias ${ }^{4}$ - A. L. Hale ${ }^{5}$ - S. E. Sattler ${ }^{2}$. J. E. Knoll ${ }^{1}$
}

Published online: 7 January 2016

(C) The Author(s) 2016. This article is published with open access at Springerlink.com

\begin{abstract}
Biofuels and bio-based products can be produced from a wide variety of herbaceous feedstocks. To supply enough biomass to meet the needs of a new bio-based economy, a suite of dedicated biomass species must be developed to accommodate a range of growing environments throughout the USA. Researchers from the US Department of Agriculture's Agricultural Research Service (USDA-ARS) and collaborators associated with the USDA Regional Biomass Research Centers have made major progress in understanding the genetics of switchgrass, sorghum, and other grass species and have begun to use this knowledge to develop new cultivars with high yields and appropriate traits for efficient conversion to bio-based products. Plant geneticists and breeders have discovered genes that reduce recalcitrance for biochemical conversion to ethanol and drop-in fuels. Progress has also been made in finding genes that improve production under biotic and abiotic stress from diseases, pests, and climatic variations.
\end{abstract}

W. F. Anderson

bill.anderson@ars.usda.gov

1 USDA/ARS Crop Genetics and Breeding Research Unit, 2360 Rainwater Road, Tifton, GA 31794, USA

2 USDA/ARS Grain, Forage and Bioenergy Research, UNL, 251 Filley Hall, East Campus, Lincoln, NE 68553, USA

3 USDA/ARS US Dairy Forage Research Center, 1925 Linden Dr. W., Madison, WI 53706, USA

4 USDA/ARS Crop Improvement and Genetics Research, WRRC, 800 Buchanan Street, Albany, CA 94710, USA

5 USDA/ARS Sugarcane Research Unit, 5883 USDA Road, Houma, LA 70360, USA
Keywords Warm-season grasses · Switchgrass · Bioenergy · Energycane $\cdot$ Napiergrass $\cdot$ Sorghum

\section{Introduction}

A number of dedicated herbaceous biomass feedstocks have been proposed to help achieve US energy independence goals [58]. Switchgrass (Panicum virgatum L.) was the first perennial grass identified as a biomass feedstock because it has high yield potential, is native to the USA, needs relatively low inputs, and can be grown in most climates of the eastern USA $[83,113]$. Other native grasses that are being developed as biomass feedstocks are big bluestem (Andropogon gerardi Vitman) and indiangrass (Sorghastrum nutans L. Nash) [59]. Giant Miscanthus (Miscanthus x giganteus (Greef and Deuter ex Hodkinson and Renvoize) is another high-yielding perennial grass that was introduced from Europe. In the southern USA, the highest yielding perennial biomass energy crops are energycane (Saccharum hyb.) and napiergrass (Cenchrus purpureus (Schumach.) Morrone; formerly Pennisetum purpureum Schumach.). These two grasses are sub-tropical in nature and are more photoperiod sensitive allowing vegetative production to continue until late fall or until frost kills the aboveground portion of the plant. Biomass and sweet sorghums (Sorghum bicolor (L.) Moench) are annual grasses that provide an opportunity to produce biomass crops in rotation with other row crops in much of the USA. Biomass yield and feedstock quality for conversion are the primary attributes addressed by plant breeders and geneticists in the development of cultivars for industrial use. This review summarizes much of the work in these areas that has been performed within the US Department of Agriculture (USDA) Regional Biomass Research Centers that were established in 2010. 


\section{Native Perennial Grass Genetics and Breeding}

Native perennial C4 grasses like big bluestem, switchgrass, and indiangrass have promise as dedicated bioenergy crops and provide opportunities for meeting the demand for bioenergy. Breeding programs for the native perennial grasses in the USA use recurrent selection methods for making incremental gains in traits and populations of interest [110]. Switchgrass matures earlier than big bluestem and indiangrass [99]. Switchgrass genotypes are either "lowland" ecotypes that are tetraploids $(4 \times)$ or "upland" ecotypes that are tetraploids $(4 \times)$, octaploids $(8 \times)$, or dodecaploids $(12 \times)$ with chromosome numbers ranging from 18 to 108 [113]. Indiangrass cytotypes are hexaploids $(6 \times)$ with chromosome numbers ranging from 20 to 80 . The bluestem complex (big bluestem and sand bluestem (Andropogon hallii Hack.)) has two cytotypes, being either hexaploids $(6 \times)$ or enneaploids $(9 \times)$, with chromosome numbers ranging from 20 to 100 . While interspecific hybrids can be produced between big and sand bluestem, hybrid production is restricted within a ploidy level in switchgrass [113].

\section{Crossing and Selection and Cultivar Development}

Restricted recurrent phenotypic selection (RRPS), combined with a between- and within-family approach, has been the method of choice for the native perennial grasses, whereby half-sib families are produced by open pollination in isolated nurseries to assess growth, survival, and phenological traits $[16,110,114]$. Individual progeny within the selected families are appraised in later years (but the same generation) for both biomass and quality traits. Selection index theory methods have been applied by combining biomass and quality traits in a linear combination that weighs them according to their relative importance based on the breeder's perspective. The index is used as a criterion to select parents for the next cycle of recombination and to evaluate progress. Each cycle takes about 5 years to complete with the potential to release a superior cultivar (i.e., a synthetic population of outstanding individuals). Cumulative gains are captured across generations.

Switchgrass, big bluestem, and indiangrass are naturally out-crossing, and cytological and molecular studies have indicated that segregation is predominantly disomic (diploid) and that quantitative genetics techniques can be applied to decipher the genetic control of traits $[62,110]$. Genetic inheritance has been assessed and used to make decisions when choosing parents and releasing cultivars $[16,43]$. Results indicated that genetic variation is ample in these crops for all the variables or traits under evaluation and that most traits are controlled by additive genetic variance, which is the most reliable means toward making genetic gains over generations. Genetic populations are generally created via open pollination, but biparental and inter-population crosses have been made to explore other sources of genetic variation $[18,55]$. Genotype-by-environment interactions are found in these populations and are expressed in the form of differential responses of families across years or across locations $[43,77]$. Cultivars released at the end of a breeding cycle are synthetic populations composed of the best families of half-sibs. As synthetic cultivars, they are buffered against biotic and abiotic stresses. However, linkage disequilibrium occurs in these "closed" breeding populations over generations and families are lost as a result of environmental stresses (e.g., freeze or pest damage). Thus, diversity must be restored by introducing new germplasm. Maintaining genetic diversity within the families is critical in preserving the capacity to generate new greater-yielding and quality options dedicated to either bioenergy platform $[17,110]$.

Genetic improvement in the warm-season grasses has resulted in the recent release of improved genetic materials with high value for the bioenergy industry. One such cultivar named "Liberty" is a switchgrass synthetic population, bred and released as the first cultivar with the bioenergy ideotype (high biomass, low stem lignin, high survival) for the Great Plains and the Midwest regions of the USA [122]. Liberty was jointly released in 2013 by the USDA's Agricultural Research Service (USDA-ARS) and by the University of NebraskaLincoln and registered as PI 669371 [122]. Liberty was evaluated in sward trials in Nebraska, Illinois, and Wisconsin in three hardiness zones (HZ 3, 4, and 5) and had better winter survival than the lowland-type cultivars and better biomass yield than the upland-type cultivars. Liberty was developed from one sub-line of the Summer x Kanlow population, which is being improved simultaneously for a combination of high biomass yield and low stem lignin. The increased biomass yield with Liberty corresponds to a conversion of about 600 additional $\mathrm{L} \mathrm{ha}^{-1}$ of ethanol if processed by a bio-refinery. The gains with Liberty can be explained by (1) the heterotic effects obtained with crossing two contrasting genotypes within the same ploidy levels [55]; (2) the effect of dominance variance for some of the traits by building the base population from controlled (fullsib) crosses; (3) the high intensity applied in selecting the best families for winter survival; (4) the favorable and high correlations among some of the traits; and (5) the integration of biomass yield and low-lignin traits into the selection index.

Breeding efforts in big bluestem have resulted in two recent cultivar releases. "Bonanza" big bluestem was jointly released in 2004 by the USDA-ARS and the University of NebraskaLincoln, NE, and registered as PI 641701 [116]. Bonanza was developed after three 5-year cycles of population improvement within the cultivar "Pawnee" using recurrent breeding (by open pollination) and selection methods. The objective was to simultaneously increase biomass (forage) yield and digestibility (in vitro dry matter disappearance (IVDMD)). "Goldmine" big bluestem was released in 2004 by the 
USDA-ARS and by the University of Nebraska-Lincoln, NE, and registered as PI 641702 [117]. Goldmine was derived from the cultivar "Kaw" and is adapted to HZ 4-5 of the Central and Southern Plains and to adjacent regions of the Midwest in the USA.

Indiangrass is an allopolyploid, and its breeding targets the improvement of cultivars in both biomass yield and digestibility (IVDMD) for hardiness zones 4 and 5 within the eastern Great Plains and Midwest USA. Researchers at the USDAARS recently released three new indiangrass cultivars. "Warrior" was released in 2008 by the USDA-ARS and the University of Nebraska-Lincoln, NE, and registered as PI 655523 [119]. After using a half-sib family selection in cycle 1 and a restricted recurrent mass selection method in the two successive cycles, Warrior was released as a stable randommated cultivar, adapted to the HZ 5 and 6 (upper part) in the Great Plains and Midwest USA. "Scout" was released in 2008 by the USDA-ARS and the University of Nebraska-Lincoln, NE, and registered as PI 655524 [119]. Two cycles of restricted recurrent phenotypic selection ultimately led to the development of Scout. A selection index that weighed biomass yield and IVDMD equally was used to select plants as parents of the two generations. Scout was released as a stable synthetic cultivar adapted to HZ 4 and 5 based on sward trials established at three locations within these two zones. "Chief" was released in 2008 by the USDA-ARS and the University of Nebraska-Lincoln, NE, and registered as PI 655525 [119]. Selection was based on biomass yield and heading date in the first cycle and for an index that combined both biomass and IVDMD in the second. Chief is best adapted to HZ 4 and 5. The release of Chief, similar to that of Liberty, emphasizes that inter-population breeding is an efficient tool to make gains in yield and quality traits for both the forage and bioenergy programs. Key in the improvement of these cultivars was the development of near-infrared reflectance spectroscopy (NIRS) equations to rapidly and accurately assess quality traits [120].

\section{Effects of Lignin Content on Recalcitrance and Survival}

Included in the large switchgrass germplasm collection at ARS-Lincoln is a six-cycle breeding nursery containing genetically related octaploid plants. These plants have been bred for three cycles for improved in vitro digestibility and one cycle for decreased in vitro digestibility [115]. Anatomical evidence indicated that stem anatomy had been significantly affected by selection for increased or decreased ruminant digestibility. Plants from high-lignin populations had extensive lignification of the cortical sclerenchyma as compared with plants from the low-lignin populations [84]. Taking a subset of plants with the highest or lowest stem lignin from each of two populations, significant differences were noticed in the overall compositional makeup of total plant biomass comprised of stems and leaves. As the first report of this kind for switchgrass, it was possible to show that cell wall accessibility to cellulases was modified in these plants $[12,88]$. In a follow-up study, using only stems obtained from these octaploid plants, the importance of cell wall architecture on final ethanol yields was established. Results showed how changes at the whole-plant level (digestibility) affected the apparent response to dilute acid pretreatment during biomass deconstruction [91]. At the ultrastructural level, the interactions between cell wall architecture and pretreatment were striking. Plants from the low-lignin, high-digestibility population had apparently much smoother cell walls and lower levels of lignin bubbles, which have been postulated to be regions that could inactivate cellulases [24, 25]. Conventional breeding strategies based on these results have been subsequently applied to generate biofuel-type tetraploid germplasm for high yields and greater conversion potential [122].

Lignin content impacts both plant and biomass parameters, and although decreased lignin content improves biochemical fermentation of biomass into liquid fuels, it has a negative impact on plant fitness. In switchgrass, lowering lignin results in decreased winter survival $[14,112]$ although the mechanisms leading to stand losses are unknown. An analysis of the effects of reduced lignin was then done on plant fitness [70]. Winter survival is of significant concern for growing switchgrass and other perennial grasses for biomass. The economics of production are strongly dependent on maintaining yields year after year [72], and even small stand losses can diminish sustainable production of biomass. Another concern is that most of the high-yielding switchgrass cultivars are lowland types with limited winter hardiness north of $40^{\circ}$ north latitude [121]. Although genotypes with superior winter survival can be selected from these base lowland populations, their survival, especially in the more northern latitudes, can be unpredictable [121]. However, inter-mating lowland switchgrass germplasm with upland germplasm that has superior winter survival in the Northern Great Plains of the USA can produce hybrids with improved yields relative to the upland populations and improved winter survival relative to the lowland genotypes [55, 118, 122].

Among the cell wall polymers, lignin presents the biggest hurdle for efficient deconstruction of cellulose and hemicellulose into liquid fuels [12] and improving saccharification efficiencies of herbaceous biomass would require bioenergy grasses with lower lignin content [23, 90]. Historically, forage breeders have known of the relationship between lignin and recalcitrance and have been successful in increasing rumen digestibility in multiple grass species. Under most circumstances, this has been due to a reduction in Klason lignin [44]. Jung et al. [45] summarized advances in the understanding and use of the genes responsible for improved digestibility or degradation of the cell wall. They noted that reduction of cinnamyl alcohol dehydrogenase (CAD) and caffeic acid-3- 
$O$-methyltransferase (COMT) enzyme activities associated with the brown midrib genes that have been used in corn (Zea mays L.), sorghum, and pearl millet (Cenchrus americanus (L.) Morrone) could be used to improve digestibility. Downregulation of CAD and COMT enzymes using biotechnological approaches have both altered lignin composition and successfully reduced Klason lignin in the walls of alfalfa (Medicago sativa L.), corn, tall fescue (Festuca arundinacea Schreb.), and switchgrass among other feedstocks $[13,42,45]$.

The information from sorghum and previous data on other grass species $[15,36]$ led to research on the relationship of lignin in switchgrass. The expectation was that strategies used in these other species could be applied to finding the switchgrass genes coding for lignin biosynthetic enzymes. Lignin biosynthesis is catalyzed by a series of enzymes [7], and putative genes coding for some of these enzymes in switchgrass were identified through expressed sequence tags (EST) sequencing projects $[105,106]$ or through cloning of specific genes using other grasses as a resource [104]. Based on work with sorghum [93], and studies ongoing in the Tobias lab (ARS-Albany, CA), a focus was placed on assaying for COMT and CAD and cloning of the enzymes responsible for lignin biosynthesis in switchgrass. Aldehyde precursors of lignin biosynthesis are reduced by CAD to generate the respective alcohols (monolignols) [7]. In most plants, genes encoding CADs are part of a family of structurally related alcohol dehydrogenases, although only one, or at most a few, are integral to lignin biosynthesis [103]. In tetraploid switchgrass, the expectation was that at least two CADs would be involved in lignification. Lignification in switchgrass stems is a continuous process, and lignin accrues in internodes until aerial senescence or a first killing frost shuts down metabolism [86]. However, maximal rates of lignification appear to occur in actively elongating internodes $[31,86]$. Using complementary DNA (cDNA) libraries generated from a variety of switchgrass tissues [106], it was possible to amplify DNA encoding two CADs, named PviCAD1 and PviCAD2 [78]. Both proteins showed a marked preference for cinnamylaldehydes and were most abundant in actively lignifying stem tissues. Phylogenetic analyses indicated that both PviCAD1 and PviCAD2 belonged to a clade of enzymes shown to be integral to lignification in other grasses suggesting that these were indeed the CADs involved in the lignification of switchgrass cell walls. RNAi studies using Alamo switchgrass confirmed the role of these CADs in cell wall lignifications [31, 79]. Site-directed mutagenesis of PviCAD1 protein based on phylogenetic and structural predictions showed the importance of specific amino acid residues for catalysis and established the importance of a specific histidine-leucine pair in the active site of all grass CADs implicated in lignification. CADs not containing these specific amino acids are unlikely to play a significant role in lignification [80].

\section{Switchgrass Survival, Dormancy, Water Use Efficiency, and Winter Hardiness}

The timing of aerial senescence and onset of dormancy of the perenniating structures toward the end of the growing season impacts harvestable biomass yields and sustainability of switchgrass stands. If aerial senescence can be delayed without affecting dormancy and winter hardiness, it could provide a means to enhance biomass yields without sacrificing sustainability of production [92]. For example, two cycles of selection for survival resulted in a modified version of the cultivar Kanlow with sufficient cold tolerance to survive in USDA hardiness zones 3 and 4 and $72 \%$ greater biomass yield compared with locally derived germplasm [18]. The molecular mechanisms controlling dormancy, winter hardiness, and survival in switchgrass need to be first understood, before they can be exploited in breeding programs. A study using the Roche Inc 454 nextgeneration sequencing (NGS) platform of the switchgrass rhizome transcriptome added over 30,000 new cDNA sequences coding for several genes that likely have an important role in winter hardiness [66]. These studies were soon followed by the release of the first draft version of the switchgrass genome (www.phytozome.org; draft 0.0 ), which was partially based on important prior work from the ARS and others $[29,61,62$, $106,128,129]$. The initial and later draft versions of the switchgrass genome [33] have significantly enabled the application of NGS to understand different aspects of switchgrass biology. ARS-initiated NGS studies have been used to analyze switchgrass leaf senescence [69], contrasting metabolism in rhizomes harvested from upland and lowland cultivars [67], global features of mineral transport genes in rhizomes [68], and class III peroxidases and their tissue expression in the switchgrass genome [81]. Additional research has strengthened the availability of genomic resources for expanding switchgrass research $[52,101,125,132]$. The development of an exome capture pipeline, based on $60 \mathrm{MB}$ of gene space [30], is currently fueling the development of genomic selection strategies for biomass yield [75] and gene discovery for flowering time and cold tolerance of switchgrass [18].

Several other aspects of switchgrass physiology and biochemistry have been investigated or reinvestigated over the last decade, including studies to understand seed dormancy in switchgrass and chemical means to improve germination $[85,87,89]$. Other work has sought to determine switchgrass water use efficiency (WUE) as compared with other forage crops. The WUE is strongly influenced by biomass production, and the high productivity of switchgrass resulted in WUE of switchgrass being four to five times that of western wheatgrass (Pascopyrum smithii (Rydb.) A. Love), which had WUE that was much more variable. Although switchgrass had the highest WUE, it also had the greatest soil water deficit. This research suggests that switchgrass is a productive bioenergy crop for the drier areas of the northern Great Plains, but its 
greater depletion of soil water may be an issue in a multi-year drought or if switchgrass is used in annual crop rotation [41].

\section{Switchgrass Genetic Diversity}

Collaborative research between ARS, The Samuel Roberts Noble Foundation, and the DOE Great Lakes Bioenergy Research Center has characterized genetic diversity in switchgrass across its native range in the USA. The research demonstrated the existence of at least 10 distinct types of switchgrass, ranging from highly drought-tolerant ecotypes of the Great Plains to highly heat-tolerant types of the Atlantic Seaboard. The work further indicated that all unique types of switchgrass originated in particular regions in the southern USA where switchgrass survived numerous Ice Ages [130, 131]. Collaborative work between ARS and other institutions has developed a mechanism to routinely assay thousands of switchgrass genotypes for DNA markers representing coding regions with 169,000 unique genes $[53,129]$. This technology is currently being applied to genotype germplasm that represents six switchgrass breeding programs in various regions of the USA [19, 34]. These results have significant implications for using a wide range of genetic and geographic diversity in many breeding programs and point to the distinct possibility of combining important biomass production traits such as late flowering, early nutrient recycling, and winter hardiness.

Growing switchgrass as a viable crop on large areas of the USA will invariably result in biotic stresses. Genetic material has been screened, and resistance has been found to pathogens $[100,133]$ and insects $[26,27,49,50,60]$ that can be exploited within breeding programs. Many of the plant mechanisms underlying these interactions are under active research scrutiny. The next decade promises to yield significant new insights into the molecular and biochemical aspects of switchgrass biology, genetics, and plant-environment interactions.

The need to understand the inherent properties of different lignocellulosic materials and how changes in production practices, harvest methods, and storage conditions influence their suitability for different industrial processes has led to cell wall physiological studies in a number of herbaceous feedstocks. An initial study by Dien et al. [22] examined the role of harvest date on biomass composition and quality in terms of its biochemical conversion to ethanol. Based partially on these findings, emphasis was placed on understanding the physiological pathways that mediate cellulose crystallinity and recalcitrance to enzymatic saccharification in the cell walls of energy grasses.

\section{Sub-Tropical Forage Biomass Traits for Conversion}

The sub-tropical climate of the southeastern USA is amenable to tall warm-season grass species that are native to continents with tropical climates, due in part to having a shorter critical photoperiod than switchgrass and giant Miscanthus. Warmseason grasses such as napiergrass and bermudagrass (Cynodon dactylon L.) are good forages because they contain highly digestible fiber, often measured as neutral detergent fiber (NDF), acid detergent fiber (ADF), and acid detergent lignin (ADL) via wet chemical analysis. Crude estimates of cellulose, hemicellulose, and lignin present in cell walls can be determined using NDF, ADF, and ADL. Though cellulose and hemicellulose make up the majority of dry biomass in forage species such as bermudagrass, the amount of lignin and the types of cross-linking with phenolic components of the cell wall have major implications on the amount of fiber that is digestible by ruminant microbes or industrial enzymes used to produce renewable fuels $[2,111]$.

Since many of the enzymes used to produce ethanol and other products from the industrial treatment of biomass were derived from microbes found in ruminants, it has been theorized that high-quality forage genotypes would also be excellent candidate feedstocks for enzymatic conversion to biofuels. For this reason, a study was conducted using 50 genetically divergent bermudagrass accessions with wide variation in fiber quality components to determine the extent of the correlation between forage quality and ethanol conversion. Anderson et al. [4] compared how multiple cell wall constituents affected both rumen digestibility as determined by in vitro dry matter disappearance (IVDMD) and conversion to ethanol via simultaneous saccharification and fermentation (SSF). A moderate, but significant, correlation was found between IVDMD and ethanol production $(r=0.55 P=0.01)$. The same study also compared IVDMD and ethanol production with net normalized gas production (NNG) after 24 and $96 \mathrm{~h}$. Ethanol production was highly correlated with NNG24 $(r=0.93 P=0.001)$ and less so with NNG96 $(r=0.63$ $P=0.001)$, while NNG96 was a much better predictor of IVDMD $(r=0.73 P=0.01)$ [4]. This was most likely due to the early conversion of cellulose to glucose and the subsequent use by the hexose-converting yeasts to ethanol. Rumen fluid that is used for both IVDMD and NNG assessments has additional enzymes that produce and utilize pentose sugars which are lacking in industrial yeasts used for SSF.

Though lignin content is a major factor in recalcitrance, differences in ethanol production also occur due to differences in cell wall architecture [91]. Anderson and Akin [2] discussed some of the aspects of cell walls that affect recalcitrance to degradation. They indicated that mesophyll cells are the most completely digested cells by rumen fluid, followed by the epidermis and parenchyma sheath cells. Xylem which has the most lignin was least degraded. Interestingly, leaf tissue that did not stain for lignin was still recalcitrant. Anderson and Akin [2] pointed out the importance of ester- and ether-linked $p$-coumaric and ferulic acids in recalcitrance to digestibility in warm-season grass cell walls. Plant breeding has been 
successful in increasing digestibility of fiber in grasses. In addition to the aforementioned reduction in lignin through genetic transformation, digestibility has been increased through breeding for reduced amount of cross-linking aromatics, such as $p$-coumaric and ferulic acids in the case of "Coastcross I" bermudagrass [2]. However, in the case of the highly digestible bermudagrass cultivar, "Tifton 85 ," the primary cause of the reduced recalcitrance toward digestibility was the high level of ester cross-linking with lignin. These ester-linked bonds in bermudagrass can be broken by rumen enzymes, whereas ether linkages seen in other varieties cannot $[2,54]$. There appeared to be a similar trend within populations of switchgrass after the initial selection for reduced lignin [111]. Subsequent selection within these populations resulted in greater amounts of $p$-coumaric acid and greater ethanol yields.

\section{Napiergrass}

Napiergrass is a valuable forage for much of the world [5, 9], and one cultivar (Mott) was released for use in the USA [102]. Napiergrass has greater ash and water content compared with switchgrass, even after frost has killed aboveground biomass [47]. The low ash and moisture content of harvested material after winter kill make switchgrass more conducive to direct combustion or pyrolysis, despite the lower yield potential than either napiergrass or energycane (Saccharum hyb.). However, if biomass is to be converted via biochemical methods, where moisture content and ash are less of an issue, napiergrass yields high levels of soluble carbohydrates compared with that of other feedstocks [1]. Anderson et al. [3] later showed significant differences in ethanol production between napiergrass genotypes and numerical differences between leaves and stems of the same cultivar. Results from research on the genetic diversity of a napiergrass nursery [39] indicated five heterotic groups. Leaves and stems of 30 of the most diverse napiergrass genotypes from that study were evaluated for biochemical conversion to ethanol. Leaves and stems of the nursery material were collected over 3 years, separated, dried, ground, and evaluated for fiber quality. Triplicate extracted samples (to avoid soluble sugars affecting ethanol yields) were treated with dilute sulfuric acid (2\%), and hydrolysates were neutralized with $\mathrm{Ca}(\mathrm{OH})_{2}$ and mixed with basal YP medium. Cellulase was added to the extracts which were subsequently inoculated with Saccharomyces cerevisiae in a simultaneous saccharification and fermentation process. The fermented product was analyzed for ethanol and xylose by high-performance liquid chromatography (HPLC). Ethanol yields ranged from 122 to $160 \mathrm{mg} / \mathrm{g}$ extracted biomass for leaves and from 64 to $127 \mathrm{mg} / \mathrm{g}$ of extracted biomass for stems, with means of 140 and $88 \mathrm{mg} / \mathrm{g}$ extracted biomass for leaves and stems, respectively (Anderson-data unpublished). Xylose means were 192 and $183 \mathrm{mg} / \mathrm{g}$ for leaves and stems, respectively. Ethanol and xylose yields from stems tended to be greater from short (dwarf) plant types that were 1.5 to $2 \mathrm{~m}$ in height than in the high-biomass types with average heights of over $3 \mathrm{~m}$. Correlation coefficients between ethanol yields and IVDMD were low and positive for leaves $(r=0.30 P=0.05)$ and slightly greater for stems $(r=0.53$ $P<.001)$. Fiber components did not significantly correlate with ethanol yields. With stem-leaf ratios over two and significant genetic variation in conversion efficiency of napiergrass stems, feedstock improvement for greater ethanol yields can likely be accomplished through traditional breeding and selection specifically for reduced stem recalcitrance. The NIRS calibrations are currently being developed from these data to assist in selection from segregating populations.

\section{Sugarcane/Energycane}

"Energycane" is a term used to describe sugarcane grown solely for the production of renewable energy. Generally, these high-fiber sugarcane varieties are derived through wide crosses of commercial sugarcane varieties (Saccharum spp.) with the wild relative $S$. spontaneum. The USDA-ARS has a longstanding germplasm enhancement program aimed at introgressing genes from wild relatives into commercial sugarcane varieties to increase disease resistance, cold tolerance, vigor, and adaptability to local growing conditions [76, 123]. Biomass yields of energycane cultivars are significantly greater than sugarcane with some clones producing more than $80 \mathrm{Mg} /$ ha dry matter (DM) in the humid tropics of Costa Rica and up to $30 \mathrm{Mg} / \mathrm{ha} \mathrm{DM}$ in southern Florida [51]. Most sugarcane production in Florida and Louisiana is on highly fertile or even muck soils. These highly fertile soils are currently under cultivation with sugarcane, and growers are not expected to displace their sugar crop for energycane due to high quotas and high price of sugar. The growing area for sugarcane in the USA is limited to Florida, South Texas, Hawaii, and southern Louisiana because of the warm climate and adequate rainfall in these areas. In the USA, the range of adaptation of the crop will need to be expanded to encompass sandy soils and colder climates outside the traditional cane-growing region if conversion of energycane to biofuel is to become an economically viable alternative to fossil fuels. In addition, varieties need to be bred for greater nitrogen use efficiency, increased ratooning ability, and lower input costs. Testing of clones on muck and sandy soils indicates a genotype-by-environment interaction [107]. This is also evident from the lack of cross-environment adaptability of sugarcane varieties. Sugarcane varieties are routinely exchanged between breeding programs worldwide, yet seldom, if ever, are varieties adapted to diverse locations. Recently, a number of energycane cultivars have been released. The first energycane cultivar to be released was "L79-1002" [6] which was later determined to have high smut (Ustilago scitaminea $\mathrm{H}$. and P. Sydow) susceptibility. The sugarcane cultivar "UFCP 74 
1010" was released in Florida as a cellulosic biomass cultivar with resistance to smut as well as to other diseases [82]. The USDA-ARS Sugarcane Research Unit in Houma, LA, in collaboration with Louisiana State University Agricultural Center, and the American Sugarcane League of the USA, Inc. released the high-fiber sugarcane cultivar "Ho 02-113" for use as a biofuel feedstock [37]. Ho 02-113 averaged 43.5 Mg/ha DM which was significantly greater than L79-1002 (37.4 Mg/ha DM) and was resistant to leaf scald (Xanthomonas albilineans (Ashby) Dawson), smut, and brown rust (Puccinia melanocephela). The released energycane varieties were grown on approximately 385 ha in the USA, with potential for expansion. In addition, these cultivars are being tested on approximately 50 ha in Central America [37].

Sugarcane is a crop that is generally adapted to tropical environments. Cold tolerance is a focus of the USDA's basic breeding program because the genes for tolerance/resistance are more likely to be found in the wild germplasm. Cold tolerance is required for economic viability of the sugarcane industry because it can extend the growing and harvest seasons and increase ratooning ability. The trait is also important when considering the use of sugarcane as a biofuel feedstock because it has the potential to expand the range of adaptation of the crop, thus reducing the need to displace sugarcane grown for sugar production. Since damaging freezes do not occur on a regular basis in the sugarcane-producing areas of the USA, a bioassay was developed to identify sources of cold tolerance among $S$. spontaneum accessions for use in future breeding. Breeders at ARS Houma, LA, evaluated $41 S$. spontaneum accessions for survival of belowground (stubble) buds after subjecting them to freezing temperatures $\left(-7{ }^{\circ} \mathrm{C}\right)$ for 6 days in a growth chamber [38]. Accessions identified as having more ratoon cold tolerance than the most tolerant tested commercial cultivar (HoCP 96-540) were IND 81-144, IND 81-80, IND 81-165, and MPTH 97-216. These clones are currently being utilized in the USDA-ARS Basic Breeding Program in Houma, LA, to increase cold tolerance in sugarcane and energycane.

As part of the ongoing effort to breed more cold-tolerant cultivars, Khan et al. [46] are attempting to develop molecular markers to hasten the breeding process. In an attempt to identify stress-tolerance genes, 465 cold-responsive markers were identified from the cold-tolerant energycane Ho 02-144 using subtractive hybridization. Expression profiles of the genes were compared with those of a cold-sensitive clone. Almost all genes were induced immediately after the cold-stress treatment and maintained their expression in Ho 02-144, whereas the cold-sensitive clones showed downregulation of the genes or little to no upregulation. The cold-responsive genes were used to derive allelically diverse simple sequence repeat (SSR) markers that were different between the cold-sensitive commercial sugarcane clones and cold-tolerant $S$. spontaneum. Currently, efforts are underway to identify functional markers associated with cold tolerance in sugarcane. Once identified, these markers will aid breeders in selecting parents and making targeted crosses to hasten the development of cold-tolerant sugar and energycane clones.

Land prone to flooding in sugarcane growing regions is frequently left fallow yet would be a candidate location for production of flood-tolerant energycane. Louisiana is prone to flooding because of its low elevation, frequent hurricanes, and tropical storms. The crop can remain underwater for many days. Two energycane clones, L 79-1002 and "Ho 02-12," were grown alongside two commercial sugarcane clones under periodically flooded and adequately drained conditions to determine if energycane would be better suited than commercial sugarcane to the flood-prone areas [108]. When the percent reduction in flooded versus non-flooded cane was compared, L 79-1002 showed no loss in biomass per hectare. In addition, under flooded conditions, L 79-1002 produced 4.0 and $6.6 \mathrm{Mg} / \mathrm{ha}$ more dry biomass than "HoCP 96-540" and "L 99-226" (both sugarcane varieties), respectively. Flooding did not affect the sucrose levels in the two energycanes, but it did affect the sucrose levels in the sugarcane varieties. Flooding reduced the stalk populations of both the energycane and sugarcane varieties; however, the energycane varieties were more highly affected. While flooding reduced photosynthesis of L 79-1002 by $50 \%$, the cultivar still had photosynthetic rates that were greater than those of the other clones because the un-stressed photosynthetic rate of this cultivar was greater to begin with. L79-1002 also had twice the number of roots as the sugarcane cultivar "HoCP 96-540." The greater root mass might contribute to flood tolerance because it supplies necessary oxygen to the plant under flooded conditions. Overall, the energycane clones tolerated the flooded conditions better than commercial sugarcane.

In Brazil, sugarcane is the primary feedstock for ethanol. The juice is extracted from harvested cane and used for crystallization of sucrose or for industrial fermentation to ethanol. Energycane cultivars can supply both convertible free sugars and cellulosic biomass as feedstock material for energy or biobased products. Nine entries were tested to determine the effects of harvest time on conversion efficiency in Tifton, GA, [48]. Type II energycane (avg $860 \mathrm{~g} \mathrm{~kg}^{-1}$ fiber) had significantly greater biomass, with "Ho 02-147" producing the highest ethanol yields of $3200 \mathrm{~L} \mathrm{ha}^{-1} \mathrm{y}^{-1}$. Timing of harvest had little effect on the biomass quality or ethanol yields of the type II energycane varieties, while high-sugar type I energycanes were more variable. However, one advantage of a late harvest was the reduction in potassium concentration as the season progressed [48].

\section{Sorghums}

Among annual crops, sweet sorghum (Sorghum bicolor L.) is an excellent source of free sugars for conversion to biofuel. Traditionally, sweet sorghum has been used as a source of 
edible syrup, but recently, there has been increasing interest as a bioenergy feedstock. Since sugarcane is seasonal and has a narrow harvest window, a complementary crop is needed to keep feedstock conversion facilities open year-round and make the process economically viable. Sweet sorghum has a complementary harvest window to sugarcane and is able to produce significant amounts of free sugars for fermentation. Previously released cultivars were pure lines and produced limited amounts of seed, but efforts are currently being made to develop hybrid sweet sorghum. Hybrid sweet sorghums are expected to significantly increase seed production which would consequently lead to the ability to plant increased acreage of the crop.

To help determine appropriate parents for a breeding program aimed at sweet sorghum improvement, a group of sweet sorghum accessions from the US germplasm collection were tested for physiological traits [124]. In addition, potential parental lines with high sugar yields and disease resistance were identified within a collection of sweet sorghum lines from multiple international sources [20]. Male sterile female parents (A-lines) have been tested with high-sugar male parents for heritability of sugar traits $[10,95]$. A number of sweet sorghum A-lines were crossed with several high-yielding pollen parents in both studies. Data from one study indicated no hybrid vigor for sugar yield, but five of six A-lines produced hybrids with similar ethanol yields as the pollen parents [95]. The authors pointed out that $91 \%$ of the variation in total ethanol yields resulted from fiber and not necessarily from free sugar concentration. In a separate group of crosses, only negative heterosis was observed for free sugar concentration in the juice, but hybrid vigor was observed for biomass yield and theoretical juice yield [20]. Both authors noted the importance of specific combining ability (SCA) and that certain hybrids produced total sugar or ethanol yields similar to their high-yielding male parents but with greater seed production.

As with grain sorghum, sweet sorghum is host to a number of disease and insect pests. A collection of primarily sweet sorghum lines was screened for resistance to fall armyworm (Spodoptera frugiperda (J.E. Smith)) under natural infestation resulting in damage ratings between 1.88 and $4.75(1=$ no damage, $4=$ lost whorl tissue, $9=$ completely defoliated) [40], suggesting that some lines carry resistance to this insect. Sugarcane aphid (Melanaphis sacchari) has been reported as an emerging serious pest on grain sorghum in Texas and neighboring states [109]. Sweet sorghum is also quite susceptible to this insect. Wang F et al. [126] identified a source of resistance to this aphid in the Chinese grain sorghum line Henong 16, and a dominant gene for resistance, RMES1, was mapped to chromosome 6 . Other potential sources of resistance in sweet sorghum are being investigated.

One of the most damaging and widespread diseases of the crop is anthracnose (Colletotrichum sublineolum), which infects the leaves and causes stalk rot. Numerous sources of resistance to this disease have been identified in sorghum, but this pathogen is also highly diverse [74], so that a particular source of resistance may be effective only in a specific region or against certain pathotypes. Breeding for stable resistance will require identification of resistance genes that are effective against a broad array of pathotypes or pyramiding multiple resistance genes within a single cultivar. Mehta et al. [56] reported a major dominant resistance locus $(C g 1)$ derived from SC748-5 which conferred resistance to anthracnose in multiple environments. Perumal et al. [73] later mapped molecular markers on chromosome 5 flanking this locus, which could be used to introgress this gene into elite germplasm. Further analysis of this locus was conducted in $117 \mathrm{~F}_{5}$ recombinant inbred lines (segregating inbred lines developed through self-fertilization to the fifth generation). These lines were screened for resistance at four locations. The major resistance locus was confirmed on chromosome 5 , and then the DNA sequences in this region were compared between the resistant (SC748-5) and susceptible (BTx623) parents. Sequencing revealed numerous amino acid changes in multiple genes, suggesting that $\mathrm{Cgl}$ is not one resistance gene but a group of several linked resistance genes. This could explain why the resistance to anthracnose conferred by $C g l$ appears to be stable across multiple environments [11]. In a separate study, pathotypes of anthracnose from Puerto Rico, Arkansas, and Texas were tested against resistant line SC112-14, and three additional resistance loci were also found on chromosome 5 [21]. This knowledge will help breeding programs to develop resistant sorghum varieties.

Brown midrib (bmr) mutants have been in used in sorghum to develop forage or cellulosic biomass sorghums with altered lignin composition [94]. In sorghum, seven $b m r$ loci have been characterized [98], but most breeding efforts have focused on a single null allele of $b m r 6$ and $b m r 12$. Forage sorghum strains with the bmr 6 and $b m r 12$ genes were discovered to have 13 and $15 \%$ less lignin, resulting in $27 \%$ and $23 \%$ greater glucose levels when treated with dilute acid and cellulase, respectively [23]. Combining these two mutations acted additively in producing $34 \%$ more glucose, resulting in $43 \%$ more ethanol when subjected to simultaneous saccharification and fermentation (SSF). Bmr6 and Bmr12 encode the major CAD and COMT enzymes in sorghum, respectively $[8,35$, 93]. Both the bmr6-ref and bmr12-ref alleles encode nonsense mutations, which result in the absence of their respective proteins $[93,96]$. Both mutations resulted in lowering Klason lignin concentrations, and $b m r 12$ greatly reduced the $\mathrm{S} / \mathrm{G}$ lignin ratio $[64,93,96]$. COMT belongs to a clade of enzymes that utilize $S$-adenosylmethionine as a methyl donor to catalyze the methylation of other compounds. Within the lignin biosynthesis pathway, methylation of 5-hydroxyconiferyl aldehyde yields sinapylaldehyde, the precursor for sinapyl alcohol and S-lignins $[64,93]$. Elucidation of these enzymes' kinetics and substrate specificities has been simplified by a new 
method developed by ARS scientists at Lincoln, NE, that relies on fluorescence as a means to detect and continuously measure the activity of these enzymes [65]. This new assay has been subsequently adopted in other studies [96].

High-yielding forage sorghum is an excellent candidate as an annual cellulosic biomass source. Pedersen et al. [71] determined that a large portion of variation in ethanol yields of sweet sorghum lines and hybrids was due to cellulosic fiber. Genes responsible for increased saccharification via enzymes have been mapped and were identified from a sorghum core collection [127]. The seven genetic loci identified with the traits in their study appeared to be responsible for cellulose biosynthesis and orientation within the secondary cell walls. Because the $b m r$ mutants have reduced lignin and reduced recalcitrance to saccharification, it was assumed that sorghum with these mutations would be more susceptible to insects and diseases. However, there is evidence that in some cases plants with modified lignin may have greater resistance [97]. One cause of greater disease resistance may be due to the increased amount of ferulic acid compounds in the mutants [32]. Leaves from mature $b m r$ plants were more resistant to corn earworm (Helicoverpa zea (Boddie)) and fall armyworm, both common insect pests, than those of the normal lignin lines, possibly due to increased vanillic acid [28].

\section{Conclusions}

Although feedstock quality for bio-based products significantly impacts conversion, the greatest economic driver of feedstock production is yield. As yield per unit area increases, transport expenses decrease, demand on arable land decreases, and overall economic returns will increase. Yield of dedicated feedstocks varies by geographic location and environment. Switchgrass, other native grasses, and giant Miscanthus are much better adapted to northern latitudes while more tropical species like napiergrass and energycane have greater potential in the south, with annual sorghum an excellent candidate for many parts of the USA. Restricted recurrent phenotypic selection methods have been used to significantly increase yields of all the major warm-season grass feedstocks addressed in this review. Genomics have been used to pinpoint traits that will directly impact crop yields and adaptation. Plant breeders must use both phenotypic and molecular genetic tools to develop high-yielding feedstocks with biotic and abiotic stress tolerance since prime cropland will be directed toward food, fiber, and feed production and biomass feedstocks will be grown on marginally productive cropland.

\section{Need for Further Research}

Over the past few years, emphasis has changed for dedicated biomass feedstock crops from cellulosic ethanol toward "drop-in" fuels such as butanol or jet fuels and bio-based products [57]. Yield and reduction of recalcitrance will continue to be of primary importance for biochemical conversion to these products. However, thermo-chemical conversion to syngas or pyrolysis oils is less reliant on differences in cell wall composition and more reliant on ash and moisture concentration [63]. Clearly, the conversion platform has a substantial influence on biomass quality traits (or anti-quality traits) that impact the conversion process, in turn influencing breeding objectives and goals. It will be important to identify germplasm with improvements in nitrogen use (NUE) and water use efficiency (WUE). Breeders have demonstrated that NUE can be improved by classical breeding, increasing biomass yield at a constant rate of nitrogen fertilizer. However, doubling biomass yield of perennial grasses without decreasing nitrogen uptake concentration will lead to increased nitrogen requirements in the long term, partially defeating the advantage of increased biomass yield. Monoculture of dedicated feedstocks has led to increased occurrences of diseases and pests. Recent efforts have just begun to identify sources of resistance to pathogens and antibiosis to insect pests. Screening of germplasm and development of cultivars with both biotic and abiotic resistance will be a high priority. Creation and implementation of routine and efficient screens for biotic and abiotic stresses is a strong research priority, especially in the face of potential global climate change. Species such as switchgrass that are still more-or-less wild possess vast amounts of genetic variability, creating opportunities to improve existing germplasm. For example, the successes of both the Lincoln, NE, and Madison, WI, switchgrass breeding programs to improve cold tolerance and combine improved survival with later flowering and high biomass yield have significantly expanded the geographic range for which switchgrass can be used to economically and sustainably produce biomass for conversion to energy.

Open Access This article is distributed under the terms of the Creative Commons Attribution 4.0 International License (http:// creativecommons.org/licenses/by/4.0/), which permits unrestricted use, distribution, and reproduction in any medium, provided you give appropriate credit to the original author(s) and the source, provide a link to the Creative Commons license, and indicate if changes were made.

\section{References}

1. Anderson WF, Peterson J, Akin DE, Morrison WH III (2005) Enzyme pretreatment of grass lignocellulose for potential highvalue co-products and an improved fermentable substrate. Appl Biochem Biotechnol 121-124:303-310

2. Anderson WF, Akin DE (2008) Structural and chemical properties of grass lignocelluloses related to conversion for biofuels. J Ind Microbiol Biotechnol 35:355-366

3. Anderson WF, Dien BS, Brandon SK, Peterson JD (2008) Assessment of bermudagrass and bunch grasses as 
feedstock for conversion to ethanol. Appl Biochem Biotechnol 14:13-21

4. Anderson WF, Dien BS, Jung HG, Vogel K, Weimer PJ (2010) Effects of forage quality and cell wall constituents of bermudagrass on biochemical conversion to ethanol. Bioenerg Res 3:225-237

5. Bayer W (1990) Napier grass - a promising fodder for smallholder livestock production in the tropics. Plant Res Dev 31:103-111

6. Bischoff KP, Gravois KA, Reagan TE, Hoy JW, Kimbeng CA, LaBorde CM, Hawkins GL (2008) Registration of 'L 79-1002' sugarcane. J Plant Reg 2:211-217

7. Boerjan W, Ralph J, Baucher M (2003) Lignin biosynthesis. Annu Rev Plant Biol 54:519-546

8. Bout S, Vermerris W (2003) A candidate-gene approach to clone the sorghum Brown midrib gene encoding caffeic acid O-methyltransferase. Mol Genet Genomics 269(2):205-214

9. Bouton J (2002) In Bioenergy crop breeding and production research in the southeast, ORNL/SUB-02-19XSV810C/01

10. Bunphan D, Jaisil P, Sanitchon J, Knoll JE, Anderson WF (2015) Heterosis and combining ability of $F_{1}$ hybrid sweet sorghum in Thailand. Crop Sci 55:178-187

11. Burrell AM, Sharma A, Patil NY, Collins SD, Anderson WF, Rooney WL, Klein PE (2015) Sequencing of an anthracnoseresistant sorghum genotype and mapping of a major QTL reveal strong candidate genes for anthracnose resistance. Crop Sci 55:110

12. Carroll A, Somerville C (2009) Cellulosic biofuels. Annu Rev Plant Biol 60:165-182

13. Casler MD, Vogel KP (1999) Accomplishments and impact from breeding for increased forage nutritional value. Crop Sci 39(1): 12-20

14. Casler MD, Buxton DR, Vogel KP (2002) Genetic modification of lignin concentration affects fitness of perennial herbaceous plants. Theor Appl Genet 104(1; 1):127-131

15. Casler MD, Pedersen JF, Undersander DJ (2003) Forage yield and economic losses associated with the brown-midrib trait in sudangrass. Crop Sci 43(3; 3):782-789

16. Casler MD, Brummer EC (2008) Theoretical expected genetic gains for among- and within-family selection methods in perennial forage crops. Crop Sci 48:890-902

17. Casler MD (2010) Changes in mean and genetic variance during two cycles of within-family selection in switchgrass. Bioenerg Res $3: 47-54$

18. Casler MD (2014) Heterosis and reciprocal-cross effects in tetraploid switchgrass. Crop Sci 54:2063-2069

19. Casler MD, Vogel KP (2014) Selection for biomass yield in upland, lowland, and hybrid switchgrass. Crop Sci 54(2):626-636

20. Cuevas HE, Prom LK, Erpelding JE (2014a) Tapping the US sweet sorghum collection to identify biofuel germplasm. Sugar Tech DOI 10.1007/s12355-014-0349-7

21. Cuevas HE, Prom LK, Erpelding JE (2014) Inheritance and molecular mapping of anthracnose resistance genes present in sorghum line SC112-14. Mol Breed 34:1943-1953

22. Dien BS, Jung HG, Vogel KP, Casler MD, Lamb JFS, Iten L, Mitchell RB, Sarath G (2006) Chemical composition and response to dilute-acid pretreatment and enzymatic saccharification of alfalfa, reed canarygrass, and switchgrass. Biomass Bioenergy 30: $880-891$

23. Dien BS, Sarath G, Pederson JF, Sattler SE, Chen H, FunnellHarris DL, Nichols NN, Cotta MA (2009) Improved sugar conversion and ethanol yield for forage sorghum (Sorghum bicolor L. Moench) lines with reduced lignin contents. BioEnergy Res 2(3): 153-164

24. Donohoe BS, Decker SR, Tucker MP, Himmel ME, Vinzant TB (2008) Visualizing lignin coalescence and migration through maize cell walls following thermochemical pretreatment. Biotechnol Bioeng 101(5):913-925

25. Donohoe BS, Vinzant TB, Elander RT, Pallapolu VR, Lee YY, Garlock RJ, Balan V, Dale BE, Kim Y, Mosier NS, Ladisch MR, Falls M, Holtzapple MT, Sierra R, Shi J, Ebrik MA, Redmond T, Yang B, Wyman CE, Hames B, Thomas S, Warner RE (2011) Surface and ultrastructural characterization of raw and pretreated switchgrass. Bioresour Technol 102(24):11097-11104

26. Dowd PF, Johnson ET (2009) Differential resistance of switchgrass Panicum virgatum L. lines to fall armyworms Spodoptera frugiperda (J. E. Smith). Genet Resour Crop Ev 56(8):1077-1089

27. Dowd PF, Sarath G, Mitchell RB, Saathoff AJ, Vogel KP (2013) Insect resistance of a full sib family of tetraploid switchgrass Panicum virgatum $L$. with varying lignin levels. Genet Resour Crop Ev 60(3):975-984

28. Dowd PF, Sattler SE (2015) Caterpillar feeding responses to sorghum leaves with altered lignin leaves. J Insect Science DOI: 10.1093/jisesa/ieu162

29. Ersoz ES, Wright MH, Pangilinan JL, Sheehan MJ, Tobias C, Casler MD, Buckler ES, Costich DE (2012) SNP discovery with EST and NextGen sequencing in switchgrass (Panicum virgatum L.). PLoS One 7(9):e44112

30. Evans J, Kim J, Childs KL, Vaillancourt B, Crisovan E, Nandety A, Gerhardt DJ, Richmond TA, Jeddeloh JA, Kaeppler SM, Casler MD, Buell CR (2014) Nucleotide polymorphism and copy number variant detection using exome capture and next-generation sequencing in the polyploid grass Panicum virgatum. Plant J. doi:10.1111/tpj.12601

31. Fu C, Xiao X, Xi Y, Ge Y, Chen F, Bouton J, Dixon RA, Wang ZY (2011) Downregulation of cinnamyl alcohol dehydrogenase (CAD) leads to improved saccharification efficiency in switchgrass. Bioenergy Res 4:153-164

32. Funnell-Harris DL, Sattler SE, Pedersen (2014) Response of Fusarium thapsinum to sorghum brown midrib lines and to phenolic metabolites. Plant Dis 98:1300-1308

33. Goodstein DM, Shu SQ, Howson R, Neupane R, Hayes RD, Fazo J, Mitros T, Dirks W, Hellsten U, Putnam N et al (2012) Phytozome: a comparative platform for green plant genomics. Nucleic Acids Res 40(D1):D1178-D1186

34. Grabowski PP, Morris GP, Casler MD, Borevitz JO (2014) Population genomic variation reveals roles of history, adaptation and ploidy in switchgrass. Mol Ecol 23(16):4059-4073

35. Green AR, Lewis KM, Barr JT, Jones JP, Lu F, Vermerris W, Sattler SE, Kang C (2014) Determination of the structure and catalytic mechanism of Sorghum bicolor caffeic acid Omethyltransferase and the structural impact of three brown midrib 12 mutations. Pant Physiol 165:1440-1456

36. Gupta SC (1995) Inheritance and allelic study of brown midrib trait in pearl millet. J Hered 86(4; 4):301-303

37. Hale AL, Dufrene EO Jr, Tew TL, Pan Y-B, Viator RP, White PM Jr, Veremis JC, White WH, Cobill R, Richard EP, Rukavina H, Grisham MP (2013) Registration of 'Ho 02-113' sugarcane. J Plant Reg 7(1):51-57

38. Hale AL, Viator RP, Veremis JC (2014) Identification of freeze tolerant Saccharum spontaneum accessions through a pot-based study for use in sugarcane germplasm enhancement for adaptation to temperate climates. Biomass Bioenergy 61:53-57

39. Harris K, Anderson W, Malik R (2010) Genetic relationships among napiergrass (Pennisetum purpureum Schum.) nursery accessions using AFLP markers. Plant Genetic Resources: Characterization Utilization 8:63-70

40. Harris-Shultz KR, Ni X, Anderson WF, Knoll JE (2015) Evaluation of whorl damage by fall armyworm (Lepidoptera: Noctuidae) on field-and greenhouse-grown sweet sorghum plants. J Entomol Sci 50(1):14-27 
41. Hendrickson JR, Schmer MR, Sanderson MA (2013) Water use efficiency by switchgrass compared with a native grass or a native grass alfalfa mixture. Bioenergy Res 6(2):746-754

42. Hopkins AA, Vogel KP, Moore KJ (1993) Predicted and realized gains from selection for in vitro dry matter digestibility and forage yield in switchgrass. Crop Sci 33(2):253-258

43. Jahufer MZZ, Casler MD (2015) Application of the Smith-Hazel selection index for improving biomass yield and quality of switchgrass. Crop Sci 55:1212-1222

44. Jung HG, Mertens DR, Payne AJ (1997) Correlation of acid detergent lignin and Klason lignin with digestibility of forage dry matter and neutral detergent fiber. J Dairy Sci 80:1622-1628

45. Jung HG, Samac DA, Sarath G (2012) Modifying crops to increase cell wall digestibility. Plant Sci 185-186:65-77

46. Khan NA, Bedre R, Parco A, Bernaola L, Hale AL, Kimbeng C, Pontif M, Baisakh N (2013) Identification of cold-responsive genes in energycane for their use in genetic diversity analysis and future functional marker development. Plant Sci 211:122-131

47. Knoll JE, Anderson WF, Strickland TM, Hubbard RK, Malik R (2012) Low-input production of biomass from perennial grasses in the Coastal Plain of Georgia, USA. Bioenergy Res 5:206-214

48. Knoll JE, Anderson WF, Richard EP Jr, Doran-Peterson J, Baldwin BS, Hale AL, Viator RP (2013) Harvest date effects on biomass quality and ethanol yield of new energycane (Saccharum hyb.) genotypes in the Southeast USA. Biomass Bioenergy 56: 147-156

49. Koch KG, Fithian R, Heng-Moss TM, Bradshaw JD, Sarath G, Spilker C (2014) Evaluation of tetraploid switchgrass (Poales: Poaceae) populations for host suitability and differential resistance to four cereal aphids. J Econ Entomol 107(1):424-431

50. Koch K, Bradshaw J, Heng-Moss T, Sarath G (2014) Categories of resistance to greenbug and yellow sugarcane aphid (Hemiptera: Aphididae) in three tetraploid switchgrass populations. Bioenergy Res 7:1-10

51. Leon RG, Gilbert RA, Comstock JC (2015) Energycane (Saccharum spp. X S. spontaneum L) biomass production, replication, and weed risk assessment scoring in the humid tropics and sub-tropics. Agronomy J 107:323-329

52. Li YF, Wang Y, Tang Y, Kakani VG, Mahalingam R (2013) Transcriptome analysis of heat stress response in switchgrass (Panicum virgatum L.). Bmc Plant Biol 13(1):153. doi:10.1186/ 1471-2229-13-153

53. Lu F, Lipka AE, Glaubitz J, Elshire R, Cherney JH, Casler MD, Buckler ES, Costich DE (2013) Switchgrass genomic diversity, ploidy, and evolution: novel insights from a network-based SNP discovery protocol. PLoS Genet 9(1):e1003215

54. Mandebvu P, West JW, Hill GM, Gates RN, Hatfield RD, Mullinix BG, Parks AH, Caudle AB (1999) Comparison of Tifton 85 and Coastal bermudgrass for yield, nutrient traits, intake, and digestion by growing beef steers. J Animal Sci 77:1572-1586

55. Martinez-Reyna JM, Vogel KP (2008) Heterosis in switchgrass: spaced plants. Crop Sci 48(4):1312-1320

56. Mehta PJ, Wiltse CC, Rooney WL, Collins SD, Frederiksen RA, Hess DE, Chisi M, TeBeest DO (2005) Classification and inheritance of genetic resistance to anthracnose in sorghum. Field Crops Res 93(1):1-9

57. Milbrandt A, Kinchin C, McCormick R (2013) The feasibility of producing and using biomass-based diesel and jet fuel in the United States. National Renewable Energy Lab, Tech. Rep. NREL/TP-6A20-58015, http://www.nrel.gov/docs/fy14osti/ 58015.pdf

58. Mitchell RB, Schmer M, Anderson WF, Jin V, Balkcom K, Kiniry J, Coffin A, White P (2016) Dedicated energy crops and crop residues for bioenergy feedstocks in the Central and Eastern US. BioEnergy Research
59. Moore KJ, Birrell SJ, Brown RC, Casler MD, Euken JE, Hanna HM, Hayes DJ, Hill JD, Jacobs KL, Kling CL, Laird D, Mitchell RB, Murphy PT, Raman DR, Schwab CV, Shinners KJ, Vogel KP, Volenec JJ (2015) Midwest vision for sustainable fuel production. Bioenergy DOI: 10.1080/17597269.2015.1015312

60. Nabity PD, Orpet R, Miresmailli S, Berenbaum MR, Delucia EH (2012) Silica and nitrogen modulate physical defense against chewing insect herbivores in bioenergy crops miscanthus $\times$ giganteus and Panicum virgatum (Poaceae). J Econ Entomol 105(3):878-883

61. Narasimhamoorthy B, Saha M, Swaller T, Bouton J (2008) Genetic diversity in switchgrass collections assessed by ESTSSR markers. Bioenergy Res 1(2):136-146

62. Okada M, Lanzatella C, Saha MC, Bouton J, Wu R, Tobias CM (2010) Complete switchgrass genetic maps reveal subgenome collinearity, preferential pairing and multilocus interactions. Genetics 185(3): 745-760

63. Orts W, Dien BS et al. (2016) Biorefinery strategies: conversion of crops and residues to bioenergy and bioproducts. BioEnergy Research XX:XXXX

64. Palmer NA, Sattler SE, Saathoff AJ, Funnell D, Pedersen JF, Sarath G (2008) Genetic background impacts soluble and cell wall-bound aromatics in brown midrib mutants of sorghum. Planta 229(1):115-127

65. Palmer NA, Sattler SE, Saathoff AJ, Sarath G (2010) A continuous, quantitative fluorescent assay for plant caffeic acid O-methyltransferases. J Agric Food Chem 58(9):5220-5226

66. Palmer NA, Saathoff AJ, Kim J, Benson A, Tobias CM, Twigg P, Vogel KP, Madhavan S, Sarath G (2012) Next-generation sequencing of crown and rhizome transcriptome from an upland, tetraploid switchgrass. Bioenergy Res 5(3):649-661

67. Palmer NA, Saathoff AJ, Tobias CM, Twigg P, Xia Y, Vogel KP, Madhavan S, Sattler SE, Sarath G (2014) Contrasting metabolism in perenniating structures of upland and lowland switchgrass plants late in the growing season. PLoS One 9(8):e105138

68. Palmer NA, Saathoff AJ, Waters BM, Donze T, Heng-Moss TM, Twigg P, Tobias CM, Sarath G (2014) Global changes in mineral transporters in tetraploid switchgrasses (Panicum virgatum L.). Front Plant Sci 4:549. doi:10.3389/fpls.2013.00549

69. Palmer NA, Donze-Reiner T, Horvath D, Heng-Moss T, Waters B, Tobias C, Sarath G (2015) Switchgrass (Panicum virgatum L) flag leaf transcriptomes reveal molecular signatures of leaf development, senescence, and mineral dynamics. Funct Integr Genomics 15:1-16

70. Pedersen JF, Funnell DL, Vogel KP (2005) Impact of reduced lignin on plant fitness. Crop Sci 45:812-819

71. Pedersen JF, Sattler SE, Anderson WF (2013) Evaluation of public sweet sorghum A-lines for use in hybrid production. Bioenergy Res 6:91-102

72. Perrin R, Vogel K, Schmer M, Mitchell R (2008) Farm-scale production cost of switchgrass for biomass. Bioenergy Res 1(1):9197

73. Perumal R, Menz MA, Mehta PJ, Katile S, Gutierrez-Rojas LA, Klein RR, Klein PE, Prom LK, Schlueter JA, Rooney WL, Magill $\mathrm{CW}$ (2009) Molecular mapping of $\mathrm{Cg} 1$, a gene for resistance to anthracnose (Colletotrichum sublineolum) in sorghum. Euphytica 165:597-606

74. Prom LK, Erpelding JE, Montes-Garcia N (2012) Chinese sorghum germplasm evaluated for resistance to downy mildew and anthracnose. Comm Biom Crop Sci 2:26-31

75. Resende RMS, Casler MD, de Resende MV (2014) Genomic selection in forage breeding: accuracy and methods. Crop Sci 54:143-156

76. Richard EP, Anderson WF (2014) Sugarcane, energy cane and napier grass. In: Karlen DL (ed) Cellulosic energy cropping systems. Wiley, New Delhi, India, pp 91-108 
77. Rose LW, Das MK, Taliaferro CM (2008) Estimation of genetic variability and heritability for biofuel feedstock yield in several populations of switchgrass. Ann Appl Biol 152:11-17

78. Saathoff AJ, Tobias CM, Sattler SE, Haas EJ, Twigg P, Sarath G (2010) Switchgrass contains two cinnamyl alcohol dehydrogenases involved in lignin formation. Bioenergy Res 4:1-14

79. Saathoff AJ, Sarath G, Chow EK, Dien BS, Tobias CM (2011) Downregulation of cinnamyl-alcohol dehydrogenase in switchgrass by RNA silencing results in enhanced glucose release after cellulase treatment. PLoS One 6(1):e16416

80. Saathoff AJ, Hargrove MS, Haas EJ, Tobias CM, Twigg P, Sattler S, Sarath G (2012) Switchgrass PviCAD1: understanding residues important for substrate preferences and activity. Appl Biochem Biotechnol 168(5):1086-1100

81. Saathoff AJ, Donze T, Palmer NA, Bradshaw J, Heng-Moss T, Twigg P, Tobias CM, Lagrimini M, Sarath G (2013) Towards uncovering the roles of switchgrass peroxidases in plant processes. Front Plant Sci 4:202. doi:10.3389/fpls.2013.00202

82. Sandhu HS, Gilbert RA, Comstock JC, Gordon VS, Korndörfer P, El-Hout N, Arundale RA (2015) Registration of 'UFCP 74-1010' sugarcane. J of Plant Reg 9:179-184

83. Sanderson MA, Adler PR, Boateng AA, Casler MD, Sarath G (2006) Switchgrass as a biofuels feedstock in the USA. Can J Plant Sci 86(5):1315-1325

84. Sarath G, Vogel KP, Mitchell RB, Baird LM (2005) Stem anatomy of switchgrass plants developed by divergent breeding cycles for tiller digestability. In: XX International Grassland Congress: Offered Papers. Edited by O'Mara FP, Wilkins RJ, 't Mannetje L, Lovett DK, Rogers PAM, Boland TM. Dublin, Ireland: Wageningen Academic Publishers; 975

85. Sarath G, Bethke PC, Jones R, Baird LM, Hou G, Mitchell RB (2006) Nitric oxide accelerates seed germination in warm-season grasses. Planta 223(6):1154-1164

86. Sarath G, Baird LM, Vogel KP, Mitchell RB (2007) Internode structure and cell wall composition in maturing tillers of switchgrass (Panicum virgatum. L). Bioresour Technol 98(16):29852992

87. Sarath G, Hou G, Baird LM, Mitchell RB (2007) ABA, ROS and $\mathrm{NO}$ are key players during switchgrass seed germination. Plant Signal Behav 2(6):492-493

88. Sarath G, Akin DE, Mitchell RB, Vogel KP (2008) Cell-wall composition and accessibility to hydrolytic enzymes is differentially altered in divergently bred switchgrass (Panicum virgatum L.) genotypes. Appl Biochem and Biotechnol 150:1-14

89. Sarath G, Mitchell RB (2008) Aged switchgrass seed lot's response to dormancy-breaking chemicals. Seed Technol 30:7-16

90. Sarath G, Mitchell RB, Sattler SE, Funnell D, Pedersen JF, Graybosch RA, Vogel KP (2008) Opportunities and roadblocks in utilizing forages and small grains for liquid fuels. J Ind Microbiol Biotechnol 35(5):343-354

91. Sarath G, Dien BS, Saathoff AJ, Vogel KP, Mitchell RB, Chen H (2011) Ethanol yields and cell wall properties in divergently bred switchgrass genotypes. Bioresour Tech 102:9579-9585

92. Sarath G, Baird LM, Mitchell RB (2014) Senescence, dormancy and tillering in perennial C4 grasses. Plant Sci 2014(217-218): $140-151$

93. Sattler SE, Saathoff AJ, Haas EJ, Palmer NA, Funnell-Harris DL, Sarath G, Pedersen JF (2009) A nonsense mutation in a cinnamyl alcohol dehydrogenase gene is responsible for the sorghum brown midrib6 phenotype. Plant Physiol 150(2):584-595

94. Sattler SE, Funnell-Harris DL, Pedersen JF (2010) Brown midrib mutations and their importance to the utilization of grasses. Plant Sci 178:229-238

95. Sattler SE, Anderson WF, Clegg MD, Pedersen JF (2012) Evaluation of public dwarf sweet sorghum A-lines for use in hybrid production. Bioenergy Res 6:91-102
96. Sattler SE, Palmer NA, Saballos A, Greene AM, Xin Z, Sarath G, Vermerris W, Pedersen JF (2012) Identification and characterization of 4 missense mutations in brown midrib 12 (Bmr 12); the caffeic O-methyltransferase (COMT) of sorghum. BioEnergy Res 5:855-865

97. Sattler SE, Funnell-Harris DL (2013) Modifying lignin to improve bioenergy feedstocks: strengthening the barrier against pathogens? Front Plant Sci 4:70

98. Sattler SE, Saballos A, Xin Z, Funnell-Harris DL, Vermerris W, Pedersen JF (2014). Characterization of novel Sorghum brown midrib mutants from an EMS-mutagenized population. G3: Genes|Genomes|Genetics

99. Sedivec KK, Tober DA, Duckwitz WL, Dewald DD, Printz JL (2008) Grasses for the Northern Plains, growth patterns, forage characteristics and wildlife values, vol I - cool-season. NDSU Extension Service R-1323. Fargo, N.D., 89 p

100. Serba DD, Uppalapati SR, Mukherjee S, Krom N, Tang YH, Mysore KS, Saha MC (2015) Transcriptome profiling of rust resistance in switchgrass using RNA-seq analysis. Plant Genome $8(2)$

101. Shen H, Mazarei M, Hisano H, Escamilla-Trevino L, Fu C, Pu Y, Rudis MR, Tang Y, Xiao X, Jackson L et al (2013) A genomics approach to deciphering lignin biosynthesis in switchgrass. Plant Cell 25(11):4342-4361

102. Sollenberger LE, Jones CS (1989) Beef production from N. fertilized Mott. elephantgrass. Trop Grassl 23:129-134

103. Tobias CM, Chow EK (2004) Structure of the cinnamyl-alcohol dehydrogenase gene family in rice and promoter activity of a member associated with lignification. Planta 220(5):678-88

104. Tobias CM, Chow EK (2005) Structure of the cinnamylalcohol dehydrogenase gene family in rice and promoter activity of a member associated with lignification. Planta 220(5):678-688

105. Tobias CM, Twigg P, Hayden DM, Vogel KP, Mitchell RM, Lazo GR, Chow EK, Sarath G (2005) Analysis of expressed sequence tags and the identification of associated short tandem repeats in switchgrass. Theor Appl Genet 111(5):956-964

106. Tobias CM, Sarath G, Twigg P, Lindquist E, Pangilinan J, Penning BW, Barry K, McCann MC, Carpita NC, Lazo GR (2008) Comparative genomics in switchgrass using 61585 high-quality expressed sequence tags. Plant Genome 1(2):111-124

107. Todd JR, Glaz BS, Irey MS, Zhao D, Hu C, El-Hout N (2014) Sugarcane genotype selection on a sand soil with and without added mill mud. Agron J 106(1):315-323

108. Viator RP, White PM, Hale AL, Waguespack HL (2012) Screening for tolerance to periodic flooding for cane grown for sucrose and bioenergy. Biomass Bioenergy 44:56-63

109. Villanueva RT, Brewer M, Way MO, Biles S, Sekula D, Bynum E, Swart J, Crumley C, Knutson A, Porter P, Parker R, Odvody G, Allen C, Ragsdale D, Rooney W, Peterson G, Kerns D, Royer T, Armstrong S (2014) Sugarcane aphid: a new pest of sorghum. Texas A\&M AgriLife Extension publication ENTO-03

110. Vogel KP (2000) Improving warm-season grasses using selection, breeding, and biotechnology. pp. 83-106. In K.J.Moore and B. Anderson (eds) Native Warm-season Grasses: Research Trends and Issues. CSSA Spec. Publ. 30. CSSA and SSSA, Madison WI, USA

111. Vogel KP, Jung HJG (2001) Genetic modification of herbaceous plants for feed and fuel. Crit Rev Plant Sci 20:15-49

112. Vogel KP, Hopkins AA, Moore KJ, Johnson KD, Carlson IT (2002) Winter survival in switchgrass populations bred for high IVDMD. Crop Sci 42(6):1857-1862

113. Vogel KP (2004) Switchgrass. In: Warm-season (C4) grasses. Edited by Moser LE, Sollenberger L, Burson B. Madison, WI: ASA-CSSA-SSSA; 2004: 561-588 
114. Vogel KP, Burson B (2004) Breeding and genetics. In: Moser LE, Sollenberger L, Burson B (eds) Warm-season $\left(\mathrm{C}_{4}\right)$ Grasses. ASACSSA-SSSA, Madison WI, USA, pp 51-96

115. Vogel KP, G. Sarath, and R. Mitchell (2005) Divergent breeding for tiller digestibility, modified leaf, sheath and stem composition of switchgrass (Panicum virgatum L.). In: XX International Grassland Congress : offered papers; Dublin, Ireland. Wageningen Academic Publishers: 116

116. Vogel KP, Mitchell RB, Klopfenstein TJ, Anderson BE (2006) Registration of 'Bonanza' big bluestem. Crop Sci 46:2313-2314

117. Vogel KP, Mitchell RB, Klopfenstein TJ, Anderson BE (2006) Registration of 'Goldmine' big bluestem. Crop Sci 46:2314-2315

118. Vogel KP, Mitchell RB (2008) Heterosis in switchgrass: biomass yield in swards. Crop Sci 48(6):2159-2164

119. Vogel KP, Mitchell RB, Haskins FA, Newell LC, Klopfenstein TJ, Erickson G, Anderson BE (2010) Registration of 'Warrior', 'Scout', and 'Chief' indiangrass. J Plt Registrations 4:115-122

120. Vogel KP, Dien BS, Jung HG, Casler MD, Masterson SD, Mitchell RB (2011) Quantifying actual and theoretical ethanol yields for switchgrass strains using NIRS analyses. BioEnergy Res 4:96-110

121. Vogel KP, Sarath G, Saathoff AJ, Mitchell RB (2011) Switchgrass. Rsc Energy Environ S 3:341-380

122. Vogel K, Mitchell R, Sarath G, Casler MD (2014) Registration of 'Liberty' switchgrass. J Plant Reg 8:242-247

123. Wang LP, Jackson PA, Lu X, Fan YH, Foreman JW, Chen XK, Deng HH, Fu C, Ma L, Aitken KS (2008) Evaluation of sugarcane $\mathrm{x}$ Sacharum spontaneum progeny for biomass composition and yield components. Crop Sci 48:951-961

124. Wang ML, Zhu C, Barkley NA, Chen Z, Erpelding JE, Murray et al (2009) Genetic diversity and population structure analysis of accessions in US historic sweet sorghum collection. Theor Appl Genet 120:13-23
125. Wang Y, Zeng X, Iyer NJ, Bryant DW, Mockler TC, Mahalingam R (2012) Exploring the switchgrass transcriptome using secondgeneration sequencing technology. PLoS One 7(3):e34225

126. Wang Y, Acharya A, Burrell A, Klein RR, Klein PE, Hasenstein KH (2013) Mapping and candidate genes associated with saccharification yield in sorghum. Genome 56:659-665

127. Wang F, Zhao S, Han Y, Shao Y, Dong Z, Gao Y, Zhang K, Liu X, Li D, Chang J, Wang D (2013) Efficient and fine mapping of RMES1 conferring resistance to sorghum aphid Melanaphis sacchari. Mol Breed 31:777-784

128. Young HA, Sarath G, Tobias CM (2012) Karyotype variation is indicative of subgenomic and ecotypic differentiation in switchgrass. Bmc Plant Biol 12:117

129. Zalapa JE, Price DL, Kaeppler SM, Tobias CM, Okada M, Casler MD (2011) Hierarchical classification of switchgrass genotypes using SSR and chloroplast sequences: ecotypes, ploidies, gene pools, and cultivars. Theor Appl Genet 122(4):805-817

130. Zhang YW, Zalapa J, Jakubowski AR, Price DL, Acharya A, Wei YL, Brummer EC, Kaeppler SM, Casler MD (2011) Natural hybrids and gene flow between upland and lowland switchgrass. Crop Sci 51(6):2626-2641

131. Zhang YW, Zalapa JE, Jakubowski AR, Price DL, Acharya A, Wei YL, Brummer EC, Kaeppler SM, Casler MD (2011) Postglacial evolution of Panicum virgatum: centers of diversity and gene pools revealed by SSR markers and cpDNA sequences. Genetica 139(7):933-948

132. Zhang JY, Lee YC, Torres-Jerez I, Wang M, Yin Y, Chou WC, He J, Shen H, Srivastava AC, Pennacchio C et al (2013) Development of an integrated transcript sequence database and a gene expression atlas for gene discovery and analysis in switchgrass (Panicum virgatum L.). Plant J 74(1):160-173

133. Zhu QH, Bennetzen JL, Smith SM (2013) Isolation and diversity analysis of resistance gene homologues from switchgrass. G3Genes Genom Genet 3(6):1031-1042 